\title{
RACIALIZED IN JUSTICE: THE LEGAL AND EXTRA-LEGAL STRUGGLES OF MIGRANT AGRICULTURAL WORKERS IN CANADA ${ }^{1}$
}

\author{
Adrian A. Smith*
}

Considerable attention has been directed at the Supreme Court of Canada's 2011 Fraser decision regarding the constitutional right to freedom of association of agricultural workers in Ontario. While these interventions rightly tend to chastise the Court's ruling denying meaningful associational rights, a marked indifference exists toward the racialized dimensions of the ruling and of agricultural labour production in Canada more broadly. But an application of the insights of critical race theory, while necessary to addressing the limits of contemporary jurisprudential and scholarly legal analysis, fails to sufficiently confront the particularities of labour exploitation embedded in Canada's temporary labour migration regime. Striving to deepen the study of racialization, labour and law in Canada, I situate the legal and extra-legal struggles of migrant agricultural workers within an anti-racist class analysis of law attentive to the ways racialization and racism infuse labour migration. The racialized class construction of migrant labour -- a "structural necessity" within agricultural production -- occurs through the imposition of politico-legal impediments organized through global capitalism and the system of national states. The analysis ends by advocating a turn away from prevailing approaches to the study and practice of labour law to a transgressive agenda concerned with openly contesting capitalist exploitation in all forms including racialized legal regulation of migrant agricultural labour.

Une attention considérable a été accordée à la décision de la Cour suprême du Canada rendue en 2011 dans l'arrêt Fraser, qui portait sur le droit constitutionnel à la liberté d'association des travailleurs agricoles en Ontario. Bien que les interventions tendent à juste titre à critiquer la décision de la Cour rejetant des droits d'association significatifs, il existe une indifférence marquée à l'égard des dimensions racialisées de la décision et de la production de la main-d'œuvre agricole au Canada d'une façon générale. Cependant, bien qu'elle soit nécessaire pour aborder les limites de l'analyse juridique savante et jurisprudentielle contemporaine, l'application des idées de la théorie raciale critique ne tient pas suffisamment compte des particularités de l'exploitation de la main-

1 An earlier version of this article was originally written and presented in 2010 for which I received helpful feedback from a number of people. Space and memory preclude me from naming them all here. That said, I would like to acknowledge the continuing support of Chris Ramsaroop and Dayna Scott who, in their own ways, pushed me to question, clarify, revise and deepen that original analysis. I am supremely grateful to Igor Gontcharov, Shanthi Senthe and Sujith Xavier, convenors of the November 2012 workshop "Re-Igniting Critical Race: A Canadian Perspective", held within Osgoode Hall Law School's "Challenging Conventions!: Putting Theory into Practice" Seminar Series, for forcing open space for engagements on law and racism within the Canadian legal academy. This article draws great inspiration from the participants of the workshop, and especially from the deft and penetrating insights of Patricia Williams, who served as the keynote speaker.

* Department of Law \& Legal Studies, Institute of Political Economy, Carleton University 
d'œuvre qui fait partie intégrante du régime canadien de migration temporaire de la main-d'œuvre. Dans le but d'approfondir l'étude de la racialisation, de la main-d'œuvre et du droit au Canada, je place les luttes judiciaires et extrajudiciaires des travailleurs agricoles migrants au sein d'une analyse antiraciste du droit qui tient compte des diverses façons dont la racialisation et le racisme influencent la migration de la maind'œuvre. La construction du travail migrant fondée sur une catégorie racialisée -- une "nécessité structurelle" dans le cadre de la production agricole -- se fait par l'imposition d'obstacles politico-juridiques organisés par le capitalisme mondial et le système des États nationaux. L'analyse se termine en préconisant l'abandon des approches actuelles relatives à l'étude et à l'exercice du droit du travail, au profit d'un programme transgressif visant à contester ouvertement l'exploitation capitaliste sous toutes ses formes, y compris la réglementation racialisée de la main-d'ouvre agricole migrante.

\section{INTRODUCTION}

On 17 December 2009, the Supreme Court of Canada heard a challenge to Ontario's statutory denial of meaningful collective bargaining rights to agricultural workers. Acting as co-counsel for the intervenors Justicia For Migrant Workers (J4MW) and the Industrial Accident Victims' Group of Ontario (IAVGO), I attended the oral hearing. ${ }^{2}$ It was a legal spectacle of remarkable proportions -- featuring, according to a court clerk in passing, perhaps the greatest number of lawyers in any one case that he had witnessed in his over fifteen-year tenure at the Court. In fact, there were so many lawyers present -- a reflection of the high stakes of freedom of association in Canada -- that the Court set up an overflow room in which the proceedings could be followed on closed circuit television.

At first quite reluctant to participate, ${ }^{3}$ I ultimately accepted the invitation to provide legal support (in effect to "carry the bags" of lead counsel) at the urging of several J4MW members who saw it as an opportunity to challenge the racist, anti-worker agenda of Canada's governing elites, ${ }^{4}$ within the state (political officials and judges), and within organized labour. ${ }^{5}$ While not entirely convinced, I ultimately

2 Ontario (Attorney General) v Fraser, 2011 SCC 20, [2011] 2 SCR 3 [Fraser].

3 The basis of my reluctance turns on an intense skepticism toward the role of courts in social change and a belief in the utility of oppositional collective action. For an analysis that has had great influence over my own orientation away from courts and toward collective organizing and action see Judy Fudge \& Harry Glasbeek, "The Politics of Rights: A Politics With Little Class" (1992) 1:1 Soc \& Leg Studies 45.

4 My particular use of the term 'anti-worker' requires clarification in light of the Supreme Court of Canada's unanimous ruling in Bedford, just released as I completed this article. Canada (Attorney General) v Bedford, 2013 SCC 72. Intriguingly, the Supreme Court ruled unanimously that Criminal Code provisions outlawing communication for the purposes of prostitution violated the constitutional rights of sex workers. Widely perceived as a pro-worker ruling, there however remains fierce debate about the extent to which the Court's ruling extends protections to the most vulnerable sex workers.

5 I would like to acknowledge the participants from IAVGO and J4MW who assembled over the course of several months to collectively and painstakingly craft the arguments advanced in the intervenors' brief. The process was not without its limits and flaws, and I and others have reflected incessantly on the type and manner of claims advanced. That said, it was cast as a political project of participatory decision-making which served as a testament to the activist commitments of those who populated the discussion. 
agreed to participate, rented robes and joined the "legal revolution", as it were. The entire experience cannot be recounted here, and, although there were certainly revealing moments of protest and solidarity and comradeship outside of the courtroom, not the least of which being the arrival of a school bus filled with supporters as well as current and former Caribbean migrant workers, suffice it to say I found the whole experience profoundly troubling. And yet it carried a certain symbolism: while the Supreme Court chamber was packed with lawyers, court clerks, the nine justices and their clerks and the main parties to the case, overwhelmingly white and class privileged -- the Caribbean migrant workers more or less were confined to the overflow room. ${ }^{6}$ It was as if the Court channelled the racist and classist incorporation of Caribbean and Mexican workers under the Seasonal Agricultural Workers Program $[\mathrm{SAWP}]^{7}$ into its allocation of the finite resource of courtroom space. It made a mockery, in fact, of the very idea of justice for agricultural workers.

The SAWP brings some twenty-five thousand workers from certain Caribbean countries and Mexico into on-farm agricultural work in Canada for a maximum of eight months a year. Although they do not comprise the majority of agricultural workers, SAWP workers are said to exist as an indispensable structural feature of agricultural production across Canada. It is this structural indispensability that makes these workers so pivotal to the issues surrounding Fraser.

My experience at the Supreme Court symbolizes the systemic ways in which migrant farm workers are deprived of human agency signalling the racialized class context in which this occurs. From my standpoint as a self-described black male lawyer, and as one of the few privileged participants in the courtroom, I was acutely aware of my position both as official 'insider' and as racialized 'other'. ${ }^{8}$ It is this particular racialized class awareness, which I seek to deploy in the ensuing analysis. My singular aim is to contest the marked indifference to the racialized class dimensions of both the Fraser ruling and the wider understandings of agricultural labour production in Canada. Employing a Marxist, anti-racist class analysis of law attentive to the ways racialization and racism infuse labour migration to Canada, I situate the legal and extra-legal struggles of migrant agricultural workers. The first section opens with a preliminary overview of critical race theory in Canada from which I distinguish the analytical approach adopted here in a key respect: a sustained interrogation of labour exploitation within capitalist social relations. The second section engages with the critical scholarship on Fraser. This is followed by, in a third section, a reflection on the significance of migrant workers' actually existing resistance. Following a sketch of Vic Satzewich's seminal account, which relies on an evaluation of the ongoing role of law and the state within Canada's SAWP, the analysis extends the leading political economy of migration framework to capture the socio-legal specificities of unfree migrant labour incorporation. Specifically, I articulate an understanding of migratory status and repatriation as the core political and legal mechanisms of labour unfreedom. Finally, I end with an attempt to sketch a way forward which inscribes not merely a migrant justice protest movement grounded on a series of 'anti's' (anti-racism, anti-capitalism, anti-imperialism, and so on), their importance notwithstanding, but more crucially a

6 I say 'more or less' because in typical activist fashion, members of J4MW managed to squeeze a couple of workers into the courtroom.

7 See Vic Satzewich, Racism and the Incorporation of Foreign Labour: Farm Labour Migration to Canada Since 1945 (New York: Routledge, 1991). [Satzewich, Farm Labour Migration]

8 For an exploration of this perspective in the law school context see Natasha Bakht et al, "Counting Outsiders: A Critical Exploration of Outsider Course Enrollment In Canadian Legal Education” (2007) 45:4 Osgoode Hall LJ 667. 
political vision, agenda and sets of generative practices aimed at confronting the racist-classist dimensions of law. My specific focus rests in carving space for scholarly contributions to the agenda by challenging the intellectual disciplining of the study of 'labour law' as it has been carried out within Canadian (and wider) scholarly circles.

\section{FROM 'CRITICAL RACE THEORY' TO ANTI-RACIST CLASS ANALYSIS OF LAW}

A formative, historically-entrenched body of legal scholarship in Critical Race Theory has emerged to reconstruct and critique the racialized colonial legal order in Canada. Much of this work has honed in on the role of the courts, and the Supreme Court in particular, in the perpetuation of racism. James Walker's groundbreaking work focused on common sensical racist notions reflected in Supreme Court jurisprudence in the first half of the twentieth century. ${ }^{10}$ A series of accounts have expounded on this analysis most notably Constance Backhouse's seminal work on the construction and enforcement of racialized hierarchy through "colour-coded" legal rulings. ${ }^{11}$ Pivotally, in rejecting "race-neutrality"12 Backhouse conceives of Canadian social relations as "built upon centuries of racial division and discrimination" whose "legacy ... infects all of our institutions, relationships, and legal frameworks". ${ }^{13}$ "To advocate 'colour-blindness' as an ideal for the modern world", as Backhouse argues, "is to adopt the false mythology of 'racelessness' that has plagued the Canadian legal system for so long ... [that] it will only serve to condone the continuation of white supremacy across Canadian society". 14

More recently, historian Barrington Walker's forage into the colonial legal archives of southwestern Ontario has produced an insightful and compelling account of racialized inequality in criminal law administration from the period of the mid-nineteenth until the mid-twentieth century. Walker identifies Canada's paradoxical 'racial liberal order' in which Black subjects experienced "full legal equality and the rights of citizenship but nonetheless legally supported racial discriminatory behaviour against them". 15 As Walker makes clear, "Black Canadians' experiences in the criminal courts resonated with

9 For a preliminary take on this see Adrian A Smith, "Racism and the Regulation of Migrant Labour" in Adelle Blackett \& Anne Trebilcock, eds, Handbook On Transnational Labour Law (Cheltenham, UK: Edward Elgar, forthcoming, 2015).

10 James W St G Walker, 'Race', Rights and the Law in the Supreme Court of Canada: Historical Case Studies (Toronto: Osgoode Society for Canadian Legal History \& Wilfrid Laurier University Press, 1997). For a critique see Tracey Lindberg, "Essential Reading on Race and Law" (2001) 74 Labour / Le Travail 185 (arguing that, among other things, Walker neglects the historical record on racism directed at Indigenous peoples). For a similar critique see Bonita Lawrence \& Enakshi Dua, "Decolonizing Antiracism" (2005) 32:4 Social Justice 120. For a forceful response see Nandita Sharma \& Cynthia Wright, “Decolonizing Resistance, Challenging Colonial States” (2008/2009) 35:3 Social Justice 120.

11 Colour-Coded: A Legal History of Racism in Canada: 1900-1950 (Toronto: University of Toronto Press, 1999).

12 Ibid at 274.

13 Ibid.

14 Ibid. But see Cecil Foster, A Place Called Heaven: The Meaning of Being Black in Canada (Toronto: HarperCollins, 2002). See also Robert Carter, "Prospects for a Post-Race Sociology" in Sean P Hier \& B Singh Bolaria, eds, Race \& Racism In 21st-Century Canada: Continuity, Complexity, and Change (Peterborough ON: Broadview, 2007$) 35$.

15 Barrington Walker, Race On Trial: Black Defendants in Ontario's Criminal Courts, 1858-1958 (Toronto: University of Toronto Press, 2010) at 3. Walker, as he acknowledges, is following fellow historian Ian McKay's celebrated analysis of Canada's "liberal order framework". See "The Liberal Order Framework: A Prospectus for a Reconnaissance of Canadian History” (2000) 81:4 Canadian Historical Review 617. 
the unequal power relations that emerged within colonial practices throughout the world". ${ }^{16}$ Others have broadened exploration of British settler colonial governance of racial differences through law by examining cross-racial contestations. Renisa Mawani, for instance, has shown how racialized legal truths were forged out of inter-racial encounters of European colonialists, Indigenous peoples, early Chinese migrants and so-called mixed-raced populations. ${ }^{17}$

Along different lines, legal scholars have undertaken studies of jurisprudence from 'critical race' perspectives. Carol Aylward's concise yet celebrated account, Canadian Critical Race Theory, adopts a critical race theoretical approach to evaluate prominent judgments in Canada and the United States. ${ }^{18}$ "Critical Race Theory methodology", according to Aylward, "requires a deconstruction of legal rules and principles and challenges the so-called 'neutrality' and 'objectivity' of laws that oppress Black people and other people of colour". ${ }^{19}$ The methodology has received uneven application across Canadian jurisprudence with the most significant take up occurring in racial profiling challenges in criminal and quasi-criminal investigations and proceedings. ${ }^{20}$

These scholarly interventions have reaped a number of penetrating insights. Whereas colonial legal historical accounts provide critical insight into the longstanding role of courts and law in the perpetuation of racism, jurisprudential accounts offer a methodological interrogation of law from within its institutions. Although appearing to point in divergent directions, and as such not indicative of a definitive way forward, nor totally useful as standalone approaches, these dual strands of Critical Race Theory, taken together, should be read as suggestive of the need for concerted opposition to racism both to and through law. Moreover, we ought not ignore that critical race theory has spawned growing official recognition of the everyday impacts of legalized racism. ${ }^{21}$ Insights and recognition notwithstanding, these interventions fall short in conceiving of the fundamental class dimensions of law and racism. Labour exploitation and wider class analysis garner meagre consideration and as such there is a failure to sustain a meaningful critique of the intersecting roles of law and racism within a capitalist society. These shortcomings, which appear quite problematic as capitalism is at its core a system of

16 Walker, ibid at 11.

17 Renisa Mawani, Colonial Proximities: Crossracial Encounters and Juridical Truths in British Columbia, 1871-1921 (Vancouver: University of British Columbia Press, 2009). For a slightly different but equally penetrating take see Sunera Thobani, Exalted Subjects: Studies in the Making of Race and Nation in Canada (Toronto: University of Toronto Press, 2007).

18 Carol A Aylward, Canadian Critical Race Theory: Racism and the Law (Halifax: Fernwood, 1999). For a more sociologically-grounded approach focused similarly on courts see Sherene Razack, Looking White People in the Eye: Gender, Race, and Culture in Courtrooms and Classrooms (Toronto: University of Toronto Press, 1998).

19 Aylward, ibid at 82-3.

20 David M Tanovich, The Colour of Justice: Policing Race in Canada (Toronto: Irwin Law, 2006); David M Tanovich, "The Charter of Whiteness: Twenty-Five Years of Maintaining Racial Injustice in the Canadian Criminal Justice System" (2008) 40 SCLR 655; Reem Bahdi, "No Exit: Racial Profiling and Canada's War Against Terrorism” (2003) 41:2/3 Osgoode Hall LJ 293. Carol Tator \& Frances Henry, Racial Profiling in Canada: Challenging the Myth of 'A Few Bad Apples' (Toronto: University of Toronto Press, 2006).

21 See e.g. Commission on Systemic Racism in the Ontario Criminal Justice System, Report of the Commission on Systemic Racism in the Ontario Criminal Justice System (Toronto: Queen's Printer, 1995); Working Group on Racial Equality in the Legal Profession, Canadian Bar Association, Racial Equality in the Canadian Legal Profession (February 1999), online: Canadian Bar Association <http://www.cba.org/cba/pubs/pdf/racial-equality.pdf $>$; Charles Smith, "Addressing Racism and Equity in Canada Today: Now More Than Ever" Law Society of Upper Canada, Race, Courts and Tribunals: Emerging Doctrines and Their Impact (Toronto: Law Society of Upper Canada, 2000). 
labour exploitation, ${ }^{22}$ are especially unhelpful when attempting to interrogate Canada's temporary labour migration regime. $^{23}$ It is on this basis that I adopt what I have termed a Marxist, anti-racist class analysis of law. In this, I draw from a range of thinkers whose core political projects have sought to examine the overlapping if not co-constitutive roles of, on one side, oppression experienced through racialization and racism and, on the other, labour exploitation and class struggle, all of this set within sustained socio-historico-legal interrogation of capitalist social relations on local and global scales. ${ }^{24}$

\section{LITIGATING AGRICULTURAL WORKERS’ RIGHTS IN CANADA}

In Fraser, the Supreme Court dealt with a constitutional challenge to the Agricultural Employees Protection Act (AEPA), an Ontario statute enacted "to protect the rights of agricultural employees while having regard to the unique characteristics of agriculture, including, but not limited to, its seasonal nature, its sensitivity to time and climate, the perishability of agricultural products and the need to protect animal and plant life". ${ }^{25}$ Championed by the United Food and Commercial Workers Union Canada (UFCW) as a component of their longstanding legal campaign to claim collective bargaining

22 This is of course the definitive understanding of Marx found throughout his rich body of written works see e.g. Karl Marx \& Friedrich Engels, The Communist Manifesto (Harmondsworth UK: Penguin Books, 1985); Karl Marx, Capital Vol I \& II (Hertfordshire UK: Wordsworth Edition, 2013).

23 In other respects, while existing critical race scholarship adopts a range of perspectives on what constitutes law, certain accounts adhere to overly formalistic conceptions of law or focus narrowly and specifically on litigation and lawyering, the outcome of which is the production of artificially truncated analyses. That said, law and society scholarship in Canada has not engaged deeply with racism, a criticism echoed in the U.S. context. See Laura E Gómez, "Looking for Race in All the Wrong Places" (2012) 46:2 Law \& Soc'y Rev 221.

24 See e.g. CLR James, The Black Jacobins: Toussaint L'Ouverture and the San Domingo Revolution (New York: Vintage Books, 1989); Frantz Fanon, Black Skin, White Masks (New York: Grove, 1967); Himani Bannerji, "Building From Marx: Reflections on Class and Race" (2005) 32:4 Social Justice 144; Himani Bannerji, Thinking Through: Essays on Feminism, Marxism and Anti-Racism (Toronto: Women's Press, 1995). Glaringly absent from the account of migrant labour regulation presented herein is attention to the role and impact of gender. I have sought to attend to the gendered and racialized class dimensions of temporary labour migration in forthcoming work. Following insights of socialist feminist political economy, my point of departure is the concept of social reproduction and the racialized class implications of temporary labour migration as it relates to the gendered productive-reproductive divide. SO 2002, c 16, s 1(1). The AEPA enumerates five specific core rights for "agricultural employees" under section 1(2): "(1) The right to form or join an employees' association; (2) The right to participate in the lawful activities of an employees' association; (3) The right to assemble; (4) The right to make representations to their employers, through an employees' association, respecting the terms and conditions of their employment; (5) The right to protection against interference, coercion and discrimination in the exercise of their rights". At issue is the ability to organize, collectively bargaining and to strike, which are circumvented under the AEPA relative to the Labour Relations Act. Evident from section 1(1) of the $A E P A$ is that the rights of agricultural workers are held out against the "unique characteristics" of agricultural production, a point to which I return below. Quite notably, the UFCW opted to construct its claims in Fraser in narrow and conservative terms, absent any insistence on the right to strike, as noted by Chief Justice Winkler writing in the unanimous decision for the Ontario Court of Appeal. Judy Fudge, "Introduction: Farm Workers, Collective Bargaining Rights, and the Meaning of Constitutional Protection" in Fay Faraday, Judy Fudge \& Eric Tucker eds, Constitutional Labour Rights in Canada: Farm Workers and the Fraser Case (Toronto: Irwin Law, 2012$) 1$ at 10. 
rights for agricultural workers, ${ }^{26}$ the Charter challenge claimed the AEPA violated the freedom of association and equality rights of agricultural workers. Considerable optimism surrounded the union's intervention in light of the 2007 decision in $B C$ Health Services ${ }^{27}$ which, in reversing the Court's earlier rulings on freedom of association in the Labour Trilogy of $1987,{ }^{28}$ appeared to offer greater possibilities for the constitutional protection of agricultural workers.

Not all saw it this way. Brian Langille, the most outspoken critic of the Supreme Court's ruling in $B C$ Health Services, pointed to the contradictory rationale of the Court's arguments for extending freedom of association. ${ }^{29}$ Langille's biting critique raised great controversy contributing to the heightened interest in the Fraser ruling, certainly within insider circles. ${ }^{30}$ Considerable attention has been paid in professional legal circles and from engaged academics and other commentators. In anticipation of the Fraser ruling, academic conferences were held, journal articles and newsprint accounts written; ${ }^{31}$ the ruling generated significant critical commentary -- including the scholarly collection that is the focus of this section of the article.

Ultimately, the Court rejected the union's challenge -- but there is a certain level of complexity found in the set of four judgments which constitute the Fraser ruling. All but one of the nine justices found the AEPA meaningfully ensured workers' freedom of association. The majority gave short shrift to the equality rights claim. Indeed, all members of the Court -- in line with the other levels of court -- proved quite dismissive of equality arguments. ${ }^{32}$

In Constitutional Labour Rights in Canada: Farm Workers and the Fraser Case, a recent collection edited by Fay Faraday, Judy Fudge and Eric Tucker, the contributors aim "to give greater emphasis to the social context out of which the decision emerged, while at the same time helping to illuminate Fraser's broader jurisprudential and institutional implications". ${ }^{33}$ The collection is populated with chapters by legal scholars, lawyers and trade unionists, as well as a sociologist and a documentary photographer, and dedicated to the memory of the injured and dead workers of the "Hampstead" accident in February 2012. ${ }^{34}$ Individual chapters by Fudge and Tucker, two of the most formidable

26 For instance, the UFCW brought forward the Dunmore case in which the Supreme Court held that the exclusion of agricultural workers from the Labour Relations Act violated their constitutional right of freedom of association. Dunmore v Attorney General (Ontario), 2001 SCC 94, [2001] 3 SCR 1016. Health Services and Support - Facilities Subsector Bargaining Assn. v British Columbia, 2007 SCC 27, [2007] 2 SCR.391, [BC Health Services].

28 Reference re Public Service Employee Relations Act (Alta.), [1987] 1 SCR 313; Public Service Alliance of Canada v Canada, [1987] 1 SCR 424; and RWDSU v Saskatchewan, [1987] 1 SCR 460.

29 See Brian Langille, "The Freedom of Association Mess: How We Got into It and How We Can Get out of It" (2009) 54 McGill LJ 177.

30 These arguments were taken up in the factum of the Appellant, the Attorney General of Ontario and in the judgment of Justice Rothstein. For a discussion see Fudge, supra note 25 at 12, in-text and note 39; 14.

31 Langille, for one, organized an invitation-only symposium entitled, "Is There a Constitutional Right to Strike in Canada?" on freedom of association and the right to strike at the University of Toronto law school in December 2009.

32 Notably, Justice Abella stood alone in contemplating the lives of agricultural workers. See Fraser at paras 348-350.

33 Fudge, supra note 25 at 3.

34 The traffic accident occurred just west of Kitchener Ontario in which ten Peruvian poultry workers and a truck driver died and 3 workers were badly injured. Tristin Hopper, "'I've never seen anything quite like this': Eleven killed in horrific Hampstead, Ontario crash" The National Post (6 February 2012), online:

$<$ http://news.nationalpost.com/2012/02/06/hampstead-crash-eleven-killed-in-horrific-southwestern-ontario-accident/>; Kate Allen Niamh Scallan, Jayme Poisson \& Wendy Gillis, "Community shattered by deaths: Farm crash mirrors 2004 
labour law historians of our time, lead off the collection followed by interventions from key actors in the Fraser case -- all of which are animated by two goals: "to tell the story of the farm workers and their attempt to secure constitutional rights at work" and "to refocus the debate over the scope of the constitutional protection of freedom of association". 35

The collection is organized around Fudge's forceful contention, set out in her introductory chapter, that Fraser tells "two stories". The "remarkable" feature of the ruling, according to Fudge, "is the extent to which, in three out of the four sets of reasons, the focus is almost exclusively jurisprudential and institutional; the distinctive legal treatment of agricultural workers is barely visible". 36 A sizeable portion of the majority judgment -- forty-eight of its 118 paragraphs -- amounts to, as Fudge asserts, defensive posturing surrounding criticisms of the majority judgment in BC Health Services. ${ }^{37}$ And while characterizing the Fraser ruling as "a defeat" for the UFCW -- if not, I would add, for the wider labour movement in the face of its now well-entrenched commitment to legalized politics ${ }^{38}$-- Fudge suggests the judicial "disagreement" marks "a brake on, and not a reversal of, the development of constitutional protection for collective bargaining". 39 Fudge chastises the Court for pursuing not "[w] hat the farm workers and their union wanted to know ... [which] was whether the $A E P A$ provided a meaningful process of collective bargaining". 40 Instead the Court pursued "whether section 2(d), properly understood and applied, requires the Ontario legislature to provide a particular form of

tragedy" The Toronto Star (7 February 2012), online: <http://www.the-

star.com/news/gta/2012/02/07/community_shattered_by_deaths_farm_crash_mirrors_2004_tragedy.html $>$; Justicia For Migrant Workers, “Tragedy Warrants Coroner's Inquest, Migrant Advocacy Group Calls on Chief Coroner to Initiate First Ever Coroner's Inquest Involving Deaths of Migrant Workers in Hampstead, Ontario" (8 February 2012), online: CNW $<$ http://cnw.ca/WAN2l $>$.

35 Fudge, supra note 25 at 28.

36 Ibid at 2.

37 Fudge, supra note 25 at 4-5; 6 (questioning the majority's focus on "a debate over the validity and cogency of the reasoning in $[B C]$ Health Services. What began as a case about whether a specific piece of legislation, the $A E P A$, provided a meaningful process of collective bargaining was transformed into one about the constitutionalization of the Wagner Act-model of collective bargaining"). Fudge traces the legislative history of the $A E P A$, enacted by the Ontario government in response to the UFCW-led Dunmore case.

38 Fudge \& Glasbeek, supra note 3.

39 Fudge, supra note 25 at $2 ; 5$.

40 Ibid at 14-15 ("They did not ask to be covered by specific legislation"). But see the Factum of the Intervener, Justicia For Migrant Workers and Industrial Accident Victims Group of Ontario, para 20-24 (arguing for a particular sectoral model of collective bargaining). Tucker appears to address this claim, if indirectly, in his chapter. As he puts it, "while it is certainly necessary to think about innovation in Canadian labour law generally, and for the situation of agricultural and other vulnerable workers in particular, agricultural workers should not have to bear the burden of waiting until new models can be embedded in Canadian industrial relations". Eric Tucker, "Farm Worker Exceptionalism: Past, Present, and the post-Fraser Future" in Faraday, Fudge \& Tucker, supra note 25 at 52. Justice Abella, as Tucker notes, makes an analogous claim in her dissent (Fraser, supra note 2 at para 351). Yet he also acknowledges that "even if farm workers had been brought within a Wagner Act model, as the Ontario Court of Appeal's judgment required, the enormous challenge of actually organizing farm workers and establishing collective bargaining would have remained" (Tucker, ibid at 55-56). With this view, I concur, and would then suggest that just as there is a need to historicize "farm worker exceptionalism", as discussed below, so too must we historicize the use and availability of labour relations models for agricultural and non-agricultural work, itself a "herculean" effort which I make no serious attempt to undertake here. 
collective bargaining rights to agricultural workers, in order to secure the effective exercise of associational rights". ${ }^{41}$

Tucker's chapter, for its part, examines the provision of particular forms or models of labour relations regulation. The chapter historicizes "farm worker exceptionalism under the law" in the Canadian context, pointing to "the invisibility of Ontario's agricultural workers" in the majority judgment in Fraser. According to Tucker, "the deep history of farm worker exceptionalism" is neglected. ${ }^{42}$ The "peculiar" and deafening "silence" of the Court, ${ }^{43}$ as Tucker puts it, may have been "necessitated by its decision to uphold the $A E P A$ through a Herculean interpretative effort to tease a duty to bargain out of a statute that clearly intended not to provide one". ${ }^{44}$ Tracing its inscription to the emergence of "a more protective regime of statutory labour law in the last quarter of the nineteenth century" ${ }^{45}$ and noting its re-inscription throughout the twentieth century, Tucker points to the Fraser ruling as an historical continuation of exceptionalism into the early twenty-first century. The historical account clears the path for a specific focus in the second part of his analysis on the possibilities for ending farm worker exceptionalism after Fraser. Here, Tucker presents us with two "crosscutting strategies" for moving forward: "to abolish formal legal exceptionalism through constitutional litigation or political pressure either to bring agricultural workers under the Labour Relations Act (LRA) or to enact an alternative but effective collective bargaining law"; or, instead, "to organize outside of the $L R A$ framework, with the aim of overcoming legal exceptionalism without formally abolishing it and, perhaps, creating more favourable conditions for the enactment of an effective statutory framework in the future". ${ }^{46}$

Like other commentators, I also seek to engage with the "messy reality" of agricultural work in Canada. But unlike most interventions, I do so with the aim of accounting for the presence of migrant farm workers within agricultural production. I argue that the two stories "intertwined" in the Fraser ruling -- the jurisprudential and the social contextual -- are recounted and critiqued without due consideration of the role of racialization and racism. A perplexing dimension of the ruling and surrounding critical commentary is the absence of engagement with how processes of racialization and racism shape the legal regulation of contemporary agricultural production in Canada. ${ }^{47}$ Moreover, the

$41 \quad$ Fraser, supra note 2 at para 18 cited in Fudge, supra note 25 at 13.

42 Tucker, supra note 40 at 31.

43 Ibid at $31 ; 32$.

44 Ibid at 32 .

45 Ibid at 33.

$46 \quad$ Ibid at 52 .

47 For instance, references to the foremost texts on the role of racialization and racism in temporary labour migration to Canada, such as those by Vic Satzewich and Nandita Sharma, both addressed below, are scarce. Tucker's chapter quite importantly cites Satzewich as an authority on unfree labour but does not fully engage with the core thesis on the role of racism in foreign labour recruitment, exploitation and retention (See Tucker, supra note 40 at 39 note 31). Labour lawyer Fay Faraday's chapter expressly engages with equality rights arguments, cites Satzewich's work, but does not articulate an explicitly anti-racist analysis. See Fay Faraday, "Envisioning Equality: Analogous Grounds and Farm Workers' Experience of Discrimination" in Fay Faraday, Judy Fudge \& Eric Tucker eds, Constitutional Labour Rights in Canada: Farm Workers and the Fraser Case (Toronto: Irwin Law, 2012) 109. Other chapters -- save for sociologist Kerry Preibisch's -- do not even broach the subject. The absence of sustained engagement with racialization and racism occurs despite the existence of equity matters at the heart of contemporary concerns within labour law practice and scholarship. See e.g. Brian Langille, "Labour Law's Back Pages" in Guy Davidov \& Langille eds, Boundaries and Frontiers of Labour Law (Oxford \& Portland: Hart, 2006) 13 (arguing that equity serves as a guiding theme of labour 
commentary lacks sustained consideration of the limitations of legal strategies for social change as they relate to the challenges of addressing racism. How do we explain this silence? ${ }^{48}$ Why are racialization and racism not compelling explanatory tools in analytical frameworks in labour law? Is the problem one of, as a Canadian political scientist noted about that field of study, "a fundamental disconnect between an academic discipline and the 'on-the-ground' experiences of the society it purports to analyze and explore" ${ }^{49}$ Or, to employ Constance Backhouse's phrase, is it one of a "stupefying innocence" about racism? $?^{50}$

\section{IV. 'RIGHTS' VERSUS 'DIRECT ACTION' APPROACHES TO MIGRANT JUSTICE}

To bemoan the absence of anti-racist accounts of Fraser is not to profess a particular commitment to seeking migrant worker justice through the courts. I am not claiming that judicial action can eradicate racism, at least not on its own, and not in the specific context of agricultural labour production -- nor for that matter in wider social relations. Historically, as critical race thinkers have taught us, Canadian courts have not done well to address racism; ${ }^{51}$ indeed, quite frequently courts have perpetuated it. Moreover, the belief that law can produce transformative social change remains highly contested. ${ }^{52}$ Although legal action has proven largely ineffectual, the search for alternative approaches to migrant worker justice exists within a legalized political climate. ${ }^{53}$ The challenge for legal scholars and others, according to some, is to evaluate these alternatives without engaging in a romantic envisioning of the potential for transformation in extra-legal practices. ${ }^{54}$ It is my contention, however, that a more

law and by implication its supporting scholarship). The anti-racist void is perplexing in a collection that strives "to reveal how legal processes, institutions, and tests tend to "screen out much of the messy reality of what may have catalyzed a legal dispute..." (emphasis added). (citing Judy Fudge \& EricTucker, "Introduction" in Judy Fudge \& Eric Tucker eds, Work on Trial: Canadian Labour Law Struggles (Toronto: Irwin, 2010) 1 at 1). See also Fudge, supra note 25 at 3 (on the adoption of a "multidimensional approach" which "reveals how the process of adjudication filters out evidence that is essential for understanding how law is involved in constructing and reproducing inequality"); Ibid at 6 (noting that, beyond issues of legal process, the multidimensional approach "helps to illuminate how legal rights are used as strategic resources in campaigns to empower precarious workers").

48 Tucker, supra note 40 at 32 (asking 'What explains this silence?')

49 Debra Thompson, “Is Race Political?" (2008) 41:3 Canadian Journal of Political Science 525 at 541.

$50 \quad$ Backhouse, supra note 11 at 278.

51 In addition to the 'critical race' sources cited earlier, one might also consider the scholarly analysis of equality rights jurisprudence under the Charter. See e.g. Bruce Ryder, Cidalia C Faria \& Emily Lawrence, "What's Law Good For? An Empirical Overview of Charter Equality Rights Decisions" (2004) 24 SCLR 103.

52 See e.g. Fudge \& Glasbeek, supra note 3; Allan C Hutchinson \& Andrew Petter, "Private Rights/Public Wrongs: The Liberal Lie of the Charter" (1988) 38:3 UTLJ 278; Didi Herman, "Beyond the Rights Debate" (1993) 2:1 Soc \& Leg Stud 25.; Byron Sheldrick, Perils and Possibilities: Social Activism and the Law (Halifax: Fernwood, 2004); Orly Lobel, "The Paradox of Extra-Legal Activism: Critical Legal Consciousness and Transformative Politics" (2007) 120 Harv L Rev 937.

53 The legalization of politics, coupled with the hegemony of human rights, both phenomena experienced in the late twentieth century, have produced an early twenty-first century rife with legalized political struggles. On the twentieth century see Michael Mandel, The Charter of Rights and the Legalization of Politics in Canada (Toronto: Wall \& Thompson, 1989).

54 Lobel, supra note 52. A great deal, according to Lobel, has been made about the cooptation of legal strategies by elites, especially lawyers and judges, in the critique of law as transformative social practice. While true, I would suggest that this confuses those sets of claims based on cooptation with ones grounded in explicitly radical participatory democratic 
stubborn challenge exists in contemplating the implications of racialization and racism in the evaluation of alternatives. Let me demonstrate through a review of the work of a pair of scholars who, in seeking to problematize legal activism, give weak consideration to racialization in temporary labour migration.

In a recent account, Jonah Butovsky and Murray Smith have argued that an impasse exists within agricultural worker organizing: a "rights-based" approach to challenging and overcoming migrant labour exploitation in agriculture in Canada stands in direct and explicit conflict with a "direct action" approach. ${ }^{55}$ In order to break the impasse, they argue, the former must give way to the latter. The prevailing rights-based approach is driven by what they term a "pacifist-legalistic" perspective which is driven by "[c]ourt challenges, moral suasion, and public education". ${ }^{56}$ The effect of this perspective, they say, is that it "seeks assiduously to avoid and even derail militant, extra-legal forms of workingclass struggle" ${ }^{57}$ In this, they single out union officialdom, but also implicate groups like J4MW, suggesting that by intervening in cases like Fraser they support a rights-based approach which "accepts as a given the permanence of capitalist exploitation". 58

I contend that Butovsky and Smith's account turns on the faulty assumption that migrant workers and their allies do not already strive to mount meaningful resistance activities outside of and independent of any legal strategies. In this, I take issue with their treatment of actually existing resistance. While I am sympathetic to the thrust of the argument, especially as a critique of late twentieth and early twenty-first century labour unionism in Canada, and as an affirmation of the crucial significance of militant direct action, the scholars have made unfounded assumptions about the actions and commitments of seasonal agricultural workers and their closest allies. Even while stressing direct action, Butovsky and Smith

theory and politics which, as a general rule, do not rest on cooptation. The social movement scholarship concerned with learning in action, for instance, demonstrates a commitment to participatory action based on radical praxis. If this is a claim about resisting cooptation it is one not contemplated by Lobel who, writing in the U.S. legal academic context where anti-capitalist politics appears even more marginalized, has adopted a highly problematic understanding of transformative social change and practices. Moreover, Lobel's critique rests on a conception of the neoliberal capitalist state as capable of ensuring social responsibility that requires far greater unpacking than occurs in her analysis. The role of the state receives greater attention below.

55 "Beyond Social Unionism: Farm Workers in Ontario and Some Lessons from Labour History" (2007) 59 Labour/Le Travail 69. The scholars ground their account in a reading of the historical record of agricultural worker organizing during a critical period of class struggle in California fields from the 1960s onwards. In addition to referencing labour history in the United States and Canada (and beyond), they marshal considerable evidence to illustrate that all of the meaningful gains achieved by agricultural workers in California (and elsewhere) came by way of militant direct action. This historical 'lesson', which for them forms an "elementary, Marxist truth", has been "obscured in recent decades owing to the bureaucratic ossification of the organized labour leadership and the hegemony within it of a socialdemocratic legalistic perspective" (Ibid at 70). While I disagree with the overly general sweep of their historical reading of agricultural labour history in California, especially with the lack of nuanced distinction between undocumented and documented migrant labour, I stand in general agreement with Butvoksy and Smith's criticism levelled at organized labour in the post-war period. In its bureaucratic leadership, the organized labour movement increasingly has opted for court action over more concentrated forms of direct action at the peril of grounded working class struggles, whether of organized and unorganized workers, employed and under- and un-employed, citizen and migrant. As well, to their credit, their account advocates an explicit commitment to anti-capitalist politics — an agenda which, as discussed below, I enthusiastically and unapologetically endorse.

$56 \quad$ Ibid at 70 .

57 Ibid.

58 Ibid. 
have not thought hard enough about the complex role of resistance in migrant workers' lived experiences. This is evident in two respects. First, the failure to perceive that migrant worker resistance occurs, in typically -- but not solely -- disjointed and covert forms, portrays these workers in terms of passivity and docility. This discounting of actually existing resistance results in under recognition of the role of racialization and racism. Second, there is a highly questionable grouping of the perceived strategies of J4MW with those pursued by the UFCW and the organized labour movement generally.

\section{A. Characterizing Migrant Worker Resistance}

The discounting of actually existing resistance ultimately results in under-recognition of how racialization and racism function to marginalize and devalue migrant workers within the labour market and wider social relations, and within the labour movement. In particular, their account depicts workers as passive actors who acquiesce to their working conditions under the SAWP -- perhaps accepting the mythology of the Canadian national state's benevolence -- and as such are unmotivated to mount concerted opposition. The treatment of workers as objects of change marks a defining feature of mainstream and certain Left accounts of global economic restructuring in the neoliberal moment. The acceptance of this analytical orientation, therefore, aligns their account with prevailing academic tendencies to objectify workers. This sort of characterization of workers takes on far more troubling meaning in the context of global South-North relations, and specifically labour migratory flows, where passivity is imbued with explicitly racialized if not racist connotations. It is reminiscent of the mythic docile slave that drove mainstream historical accounts of New World slavery throughout much of the twentieth century -- and that arguably continue to hold certain popular and scholarly sway. The crucial point, then, is not to counter the narrative by posing an inverted representation of workers in a state of perpetual rebelliousness. Rather, it is to say that migrant agricultural workers, to borrow a phrase, are not "like an empty vessel that can be filled with any rubbish that capitalists like". 59 These workers actually do mount resistance, including in direct and militant forms, in their daily lives -- a point to which I return below. Notwithstanding the difficulties of unearthing migrant worker resistance, ${ }^{60}$ I suggest that a reorientation in fundamental assumptions leads us to pursue a different line of inquiry and course of action.

\section{B. Migrant Workers and their Allies}

Butovsky and Smith's intervention also misrepresents actually existing resistance as it relates to migrant worker allies, namely J4MW. The discounting of this resistance is evident in the grouping of the perceived strategies of J4MW with those pursued by the UFCW and the wider organized labour movement.

59 Victor Satzewich, "The Political Economy of Race and Ethnicity" in Peter Li ed, Race and Ethnic Relations in Canada, 2nd ed (Toronto: Oxford University Press, 1999) 311 at 325.

60 For instance, an issue that emerges frequently in qualitative research projects with migrant workers is the lack of trust exhibited by workers toward academics and other non-migrants. See Adrian A Smith, "Legal Consciousness and Resistance in Caribbean Seasonal Agricultural Workers" (2005) 20:2 CJLS 95. 


\author{
I am deeply concerned by the characterization of J4MW as an organization that favours "pacifist- \\ legalism" over direct action. ${ }^{61}$
}

61 Fundamentally, in a certain respect, I am questioning the empirical basis on which they reached this determination. My own involvement as an activist-scholar engaged with J4MW, which self-identifies as an anti-racist and anti-capitalist activist collective, does not accord with Butovsky and Smith's characterization. Since 2004, I have witnessed, and at times participated, in substantial organizing efforts of J4MW, not the least of which include regular engagement with workers through formal and impromptu meetings. Further, I have been privy to a number of worker-led demonstrations and direct actions in which J4MW organizers assumed supportive roles. Indeed, the historical origins of J4MW rest with the marginalization of activists within organized labour and the ensuing support for a wildcat strike in southwestern Ontario. These experiences defy the overly simplistic characterization contained in Butovsky and Smith's account. Some of these actions -- including farm-specific collective withdrawals of labour power -- are catalogued as both "public" and "hidden" transcripts, to borrow James Scott's formulation, in the minds and lived experiences of workers and activists. See James C. Scott, Domination and the Arts of Resistance: Hidden Transcripts (New Haven CT: Yale University Press, 1990). Yet certain political demonstrations provide public evidence of the existence of actually existing resistance. Held on October 10th, 2010, the Pilgrimage to Freedom represents a recent example of this. It marked a fifty-kilometre trek of migrant workers and their allies from Leamington Ontario, the self-described "Tomato Capital of Canada", to the Tower of Freedom monument commemorating the underground railroad on the shores of the Detroit river in Windsor. Several J4MW organizers functioned alongside and in support of workers to organize the historic march. See David Goutor \& Chris Ramsaroop, "No Thanksgiving for migrant workers" The Toronto Star (8 October 2010), online: <http://www.thestar.com/opinion/editorialopinion/article/872459--no-thanksgiving-for-migrantworkers $>$. For a scathing critique of organized labour's lack of support for the Pilgrimage see Ajamu Nangwaya, "Farm Workers: 'dis is not slavery/ just poverty / speaking to democracy"' Dissident Voice: A Radical Newsletter in the Struggle for Peace and Social Justice (14 October 2010), online: <http://dissident-voice.org/2010/10/farm-workers-“disis-not-slavery-just-poverty-speaking-to-democracy"/>. A year later the Pilgrimage to Freedom Caravan was held over two weekends in which participants made stops in key sites connected with the underground railroad and early black settlement in southwestern Ontario, including Windsor, Leamington, Chatham, Dresden, Simcoe, Brantford, Hamilton and Toronto.

However, in another respect, I also wish to reject the counter-temptation to speak for the J4MW collective, for an articulation of their activities on the terms constructed by Butovsky and Smith's account only can come across in a defensive and uncritical way. At the core of the group are committed activists who can better contextualize the group's historical emergence at the margins of working-class politics in Canada. My own intervention should not be read as an effort to articulate an authoritative account of J4MW's now decade-long project; neither as an assertion that social movements are above serious critique. In activist and scholarly efforts to bring about a just and humane world, social movements ought not operate with any special immunity from rigorous interrogation. My unwillingness here to 'be the voice' of J4MW is not meant as a portrayal of their or all social movement activism in unproblematized terms. The point is not to valorize, fetishize or otherwise romanticize social movements. As Aziz Choudry and Dip Kapoor rightly caution, following Griff Foley, "learning through involvement in social struggles ... can ... be contradictory and ambiguous, and indeed can sometimes support the status quo." "Learning From the Ground Up: Global Perspectives on Social Movements and Knowledge Production" in Aziz Choudry \& Dip Kapoor, eds, Learning From the Ground Up: Global Perspectives on Social Movements and Knowledge Production (New York: Palgrave MacMillan, 2010$) 1$ at 3. The task, therefore, is to assert that rigorous interrogation of the kind to which we should aspire requires sustained engagement and careful empiricism. There is a need to deepen the understanding of the role of J4MW in migrant worker resistance. In this respect, I encourage academics wishing to critically explore the work of J4MW in Canada's SAWP and wider Temporary Foreign Workers Program to provide the opportunity for J4MW's core members to write and reflect on the group's own historical origins, collective political commitments, tactics and strategies. In this, I am cognizant of the use of this article as a blanket statement representative of J4MW. This is not accurate, nor is it fair to the group's core members. It is long-standing academic fashion to pass the disclaimer that the work and errors are the fault of the author; but this is all the more the case in this article. Accounts that fall well short of these aspirations only serve to encourage defensive posturing from social movement activists and to reinforce distrust for the intentions of well- 
Butovsky and Smith's analytical approach, although helpful and committed, suffers key deficiencies in its assumptions about the modes of resistance in which migrant workers and their allies are engaged. At its worst, the account comes perilously close to ivory tower elitism based on a subtle but still pernicious form of victim-blaming on one hand and (empirical) disengagement on the other. Ultimately, this boils down to reliance upon the deeply flawed belief that SAWP workers acquiesce to the conditions of subordination. Elsewhere, I have initiated preliminary reflection on how faulty claims about legal ignorance inform such assumptions. ${ }^{62}$ My intervention here -- although not contesting legal ignorance claims -- similarly is driven by a deep questioning of the value of holding worker acquiescence as a default assumption for critical interrogation of capitalism generally, and unfree labour migration specifically. In cases such as these where worker resistance tends to be covert or difficult to unearth and complicated by racism, we should opt for a different point of departure that does not undermine the potential of existing political actions. If we were to take ongoing resistance efforts as an empirical given, and still take the obstacles equally seriously, we could construct accounts capable of fortifying -and not undermining -- worker-led fight back. The challenge, in other words, is to develop a praxis committed to consolidating, broadening and fortifying existing worker resistance by deepening our understanding of the prevailing impediments. Put slightly differently, the discounting of actually existing resistance advanced by and with workers diverts meaningful attention away from examining the factors that inhibit sustained direct action. What is needed, therefore, is a more productive and sustained engagement with the specific political and legal impediments to worker resistance. In this we must see that, and here is the indispensable point, the existence of racialized migrant labour in agricultural production is not a historical accident but rather a telling feature of the politico-legal regulation of temporary labour migration.

\section{The Political and Legal Specificities of Unfree Labour Incorporation}

Any serious account of the SAWP must begin with Vic Satzewich's seminal and unsurpassed intervention, Racism and the Incorporation of Foreign Labour, published in 1991. ${ }^{63}$ Satzewich's rich analysis provides a sound foundation upon which to construct an account of the legal regulation of migrant labour. Examining the link between labour migration and capitalist development, he focuses on the deployment of foreign labour in agricultural production in twentieth-century Ontario. For Satzewich, foreign-born workers are subject to differential incorporation in social relations of production in Canada based on racialized and indeed racist characterizations of their productive capacities. To this end, the analysis demonstrates that while various sources of labour were drawn upon, from youth to unemployed workers to war veterans, racialized workers from the global South persistently were subjected to labour unfreedom. Whereas World War Two veterans from Poland initially were incorporated as unfree labour but gradually had those unfreedoms removed, Caribbean peoples systematically were incorporated as unfree migrant labour without reasonable prospects for

meaning and committed activist-scholarship. That said, conflation of groups like J4MW with trade unions serves to undermine the distinct if varied efforts of committed activists, including in J4MW, who largely operate on the margins of the labour movement. That marginalization, to be clear, stems from radical political commitments that explicitly run counter to organized labour leadership as well as from the racialized othering of J4MW's core organizers.

62 See Smith, supra note 60.

63 Satzewich, Migrant Farm Labour, supra note 7. 
improvement. This deliberate and ongoing mode of unfree migrant labour incorporation, on Satzewich's account, constitutes racism. ${ }^{64}$

The SAWP expanded to incorporate workers from Mexico in the mid-1970s ${ }^{65}$ and, through the creation of the program formerly known as the Pilot Project for Hiring Foreign Workers in Occupations that Require Lower Levels of Formal Training (now referred to as the Agricultural Stream and the Stream for Lower-skilled Occupations ${ }^{66}$ ) in the early 2000s, workers from Guatemala, the Philippines, Thailand and elsewhere. ${ }^{67}$ Unfree migrant labour remains a persistent feature of agricultural labour recruitment and retention in the twenty-first century. The explanatory significance of unfree migrant labour incorporation turns on its rejection of liberal integrationist theory and the notion of assimilation, and its recognition of the pivotal role assumed by the Canadian state. For Satzewich, the state constructs the conditions of labour unfreedom and capital accumulation through the use of political and legal compulsion. Others have noted how the sending state apparatuses perform the "heavy lifting" and, in this regard, call for an expanded, transnational or anti-imperialist framework of analysis. ${ }^{68}$ In the spirit of these calls, the task here is to push beyond general recognition of the existence of unfree labour to address the specific mechanisms of incorporation deployed by participating capitalist states.

Within capitalist relations, the state inevitably resorts to law to mediate the contradictions that arise within relations of production. ${ }^{69}$ For free waged labour, the state's ongoing and persistent intervention occurs in ways generally consistent with the exaction of labour power through, in Marx's phrase, dull economic compulsion. ${ }^{70}$ Law and the state typically constitute markets ${ }^{71}$ so compulsion occurs through the contingencies of state and legal intervention and where labour unfreedom exists, compulsion takes

64 Set within a 'structuralist' political economy framework, Satzewich conceives his Marxist account as extending the burgeoning approach developed by sociologists Singh Bolaria and Peter Li. On this front, he makes three supporting claims. First, the state assumes a pivotal role in "organizing" and "controlling" the trans-border relocation of workers spatially. Second, political and ideological relations assume central importance in structuring migration flows. Third, varying forms of migration exist under capitalism. Satzewich contests the perspective that unfree labour applies only to pre-capitalist or primitive accumulation. In his words, "the presence of relations of production using unfree labour has not been confined to the 'prehistory' of capitalism in Canada" (Ibid at 10).

Tanya Basok, Tortillas and Tomatoes: Transmigrant Mexican Harvesters in Canada (Montreal: McGill-Queen's University Press, 2002). See also Vic Satzewich, "Business or Bureaucratic Dominance in Immigration Policymaking in Canada: Why was Mexico Added to the Caribbean Agricultural Workers Program in 1974?" (2007) 8:3 Journal of International Migration and Integration 255 [Satzewich "Business"].

66 See Human Resources and Skills Development Canada, "Hiring Agricultural Workers", online: $<$ http://www.hrsdc.gc.ca/eng/jobs/foreign_workers/agriculture/index.shtml $>$.

67 For a discussion see, Judy Fudge \& Fiona McPhail, "The Temporary Foreign Worker Program in Canada: Low-skilled Workers as an Extreme Form of Flexible Labour” (2009) 31:1 Comp Lab L \& Pol'y J 5.

68 Irving André, "The Genesis and Persistence of the Commonwealth Caribbean Seasonal Agricultural Workers Program in Canada" (1990) 28 Osgoode Hall LJ 243. In a different context see Robyn Magalit Rodriguez, Migrants for Export: How the Philippine State Brokers Labour to the World (Minneapolis: University of Minnesota Press, 2010).

69 Judy Fudge \& Eric Tucker, Labour Before the Law: The Regulation of Workers' Collective Action in Canada, 1900-1948 (Toronto: Oxford University Press, 2001), see especially the "Introduction". The essential legal relations of private property, contract and credit underpin capitalist law enforcing a privileged place for individual ownership and for the exaction of labour power.

70 See Capital, Vol. I. (Moscow: Progress Publishers, 1954) at 737.

71 Douglas Hay \& Paul Craven, "Introduction" in Douglas Hay \& Paul Craven, eds, Masters, Servants, and Magistrates in Britain and the Empire, 1562-1955 (Chapel Hill: University of North Carolina Press, 2004) 1. 
on added intensity. Rather than posing the free-unfree distinction as "a simple antinomy of slavery and freedom", 72 therefore, unfree labour connotes an intricate and nuanced continuum "where direct physical and/or politico-legal compulsion are used to acquire and exploit [and retain] labour power". ${ }^{73}$ It therefore is important to see that, while the exaction of labour power under the SAWP is organized around economic compulsion, the politico-legal specificities of unfree labour incorporation deepen and intensify this process. In this way, I characterize temporary labour migration schemes such as the SAWP as facilitating super or hyper-exploitation. ${ }^{74}$ The incorporation of SAWP workers as unfree migrant labour occurs through specific mechanisms designed not only to hyper-exploit workers, but also to acquire and retain their labour power on an ongoing but seemingly provisional basis. ${ }^{75}$

\section{Mobilizing and Immobilizing Unfree Migrant Labour}

Canada's temporary labour migration regime is organized on the politico-legal compulsion of migrant labour unfreedom, understood as a set of social relations constituted through law. These relations shape the working and living conditions of disaffected workers. Through the imposition of labour unfreedom, the Canadian state intervenes to ensure capitalist appropriation of surplus labour. The coercive politico-legal intervention of the Canadian state is necessary for extracting surplus labour from foreign workers -- but the Canadian state does not act alone. Within contemporary global capitalism and the nation-state system, the hierarchical relations of states are set within more-or-less universal acceptance of the formal equality of national states, and within neoliberal globalization, unfolding in ways that racialize (and otherwise inferiorize) people from the global South. In other words, socioeconomic hierarchies and inequalities within, across and between national states are put to productive use in temporary labour migration regimes like the SAWP. As a way of accounting for these impacts beyond the Canadian state the aim, methodologically speaking, is to transnationalize the analysis of unfree migrant labour production.

72 Nigel Bolland, The Politics of Labour in the British Caribbean: The Social Origins of Authoritarianism and Democracy in the Labour Movement (Kingston, Jamaica: Ian Randle, 2001) at 10-11.

73 Robert Miles, Capitalism and Unfree Labour: Anomaly Or Necessity? (London: Tavistock Publications, 1987) at 31; 171.

74 Marx used the term "super-exploitation". However, I prefer to characterize this as hyper-exploitation in line with the heightened emphasis on time-space compression in contemporary social theorizing of neoliberal capitalist globalization. See e.g. David Harvey, The Condition of Postmodernity: An Enquiry into the Origins of Cultural Change (Cambridge, MA: Blackwell, 1990).

75 At first glance, the borrowed idea of "permanent exceptionalism" appears as an apt description of the provisional but continuing nature of labour unfreedom. For its original usage see Leo Panitch \& Donald Swartz, From Consent to Coercion: The Assault on Trade Union Freedoms, 3rd ed (Toronto: Garamond, 2003). In one sense, permanent exceptionalism is explained by the unevenness of capitalism which imposes a desperate need on people to turn to the market, and in so doing to cross territorial borders, to secure subsistence. It puts people who migrate "in situations where they can be named as foreigners and denied the same rights that citizens lay claim to" Nandita Sharma, Home Economics: Nationalism and the Making of 'Migrant Workers' in Canada (Toronto: University of Toronto Press, 2006) at 143. That said, while appearing an apt descriptor, permanent exceptionalism does not fully capture the essential continuity of capitalist relations, the rendering of productive labour or what is later termed pacification, which proves anything but exceptional. Permanent exceptionalism also seems to suggest that mobilization functions alone when in fact immobilization proves an equally (if not more) incisive force. It is important to examine the specific ways in which SAWP workers are both mobilized and immobilized. 
The legal regulation of migrant labour can be understood with greater precision, through the dynamic of what historian Prabhu Mohapatra terms 'mobilize to immobilize'. ${ }^{76}$ More specifically, political and legal mechanisms derive from, on one hand, the Canadian federal immigration regulation regime, the SAWP country-to-country agreement and sending state migration policies and, on the other, the provincial employment and labour regulation regime and the SAWP's standard employment contract. ${ }^{77}$ Whereas typically treated as isolated and discrete, these legal regulatory spheres function and interact in ways that both mobilize and immobilize workers. ${ }^{78}$ The mobilization largely — but not solely — occurs to satisfy the demands of agricultural capital. Coordinated through the efforts of Citizenship and Immigration Canada and Human Resources and Skills Development Canada, employers determine their employment needs and make an application for the recruitment of foreign workers. In preparation for sending workers abroad, the states of origin undertake a sorting of the labour stock. Prospective workers are subjected to an often medicalized prodding and probing by sending states under the pretext of determining their desirability for strenuous activities of agricultural production. ${ }^{79}$

Functioning to immobilize SAWP workers, contemporary immigration regimes distinguish foreign or migrant workers from citizen or near-citizen workers -- a distinction drawn to justify differential treatment. As non-citizens, migrant workers must secure a state-issued work permit and are subject to deportation. With respect to work permissions, SAWP workers are tied exclusively to a specific employer within a defined geographic locale. In this respect, workers experience severely circumscribed labour market and spatial mobility within Canada. ${ }^{80}$ They are permitted to remain in Canada only for a defined period typically not greater than eight months after which time they are required to return to their country of origin. During their authorized period of stay, migrant labourers may not alter the conditions of their authorization, change occupations or take on additional employment without the written approval of a federal immigration official.

Under the SAWP's country-to-country agreement, the coercive authority of the state is extended to growers through the repatriation authority. In granting authority to growers to make repatriation determinations, the SAWP agreement imposes an obligation on workers who have not completed their contractual term to cover the costs of return travel. These repatriation decisions can occur without any justification advanced by growers. Accordingly, repatriation serves as a far-reaching and decisive

76 Prabhu P Mohapatra, “Assam and the West Indies, 1860-1920: Immobilizing Plantation Labour” in Hay \& Craven, supra note $71,455$.

77 In Canadian and American legal practice and academic treatments, employment and labour law tend to be regarded as distinct areas of practice and knowledge production. Here, this distinction has only analytical relevance as, ultimately, my claim is that the functioning of both employment and labour law are obstructed by the repatriation authority of the state which primarily develops out of immigration law.

78 See e.g. Veena Verma, The Mexican and Caribbean Seasonal Agricultural Workers Program: Regulatory and Policy Framework, Farm Industry Level Employment Practices, and the Future of the Program under Unionization (Ottawa: North-South Institute 2003); Sharma, supra note 75.

79 For an in-depth account see Janet McLaughlin, Trouble in our Fields: Health and Human Rights among Mexican and Caribbean Migrant Farm Workers in Canada, (Ph.D Dissertation, University of Toronto, 2009) [unpublished] ch 4; Janet McLaughlin, "Classifying the 'ideal migrant worker': Mexican and Jamaican Transnational Farmworkers in Canada” (2010) 57 Journal of Global and Historical Anthropology 79.

80 An example relates to their inability to access social services and interact with local communities in general. Further, they are denied citizenship status and are not permitted to receive credit for their time spent in Canada, if they were to apply for Canadian citizenship. 
mechanism of immobilization capable of securing strict compliance of workers to the dictates of the SAWP and specific growers. It constitutes a very real threat that overhangs SAWP relations of production. In all, this regulation imposes tight and onerous restrictions on participating workers. It immobilizes workers through the imposition of precarious migratory status, ${ }^{81}$ as well as constraints on labour market circulation and geographic mobility. Workers encounter additional forms of immobilization stemming from provincial employment and labour law. Most notably, workers are immobilized in terms of employment standards protections and their capacities to freely associate, based on farm worker exceptionalism, although this occurs differentially throughout Canada. ${ }^{82}$

\section{Unfreedom of Association}

Fraser marked a failed attempt to challenge the constitutionality of the AEPA. Even if it had been successful, the dominant post-war model of industrial unionism, which includes organizing workplaces on an employer-by-employer basis (in contrast, for instance, to sectoral forms of organizing) produces very real disadvantages for SAWP workers. But even if we were to accept the highly debatable proposition that industrial unionism provides a viable model of collective representation for agricultural production, or that the limits of industrial unionism should not detract from agricultural worker freedom of association, a far more trenchant challenge remains. Precarious migratory status and the threat of repatriation presents a seemingly impenetrable obstacle to the wide dispersal of industrial unionism in agriculture. The idea that workers subject to the repatriation whims of growers are free to engage in collective organizing efforts is fundamentally flawed. In this way, the immobilization of migrant agricultural workers through immigration regulation presents the crucial challenge. Any gains made in terms of the labour rights and protections of migrant workers within agriculture will likely be stifled by other mechanisms of immobilization grounded in migratory status and repatriation.

For example, supporters of unionization may invoke the anti-reprisal protection in employment standards legislation. ${ }^{83}$ However, I would argue that the threat of repatriation circumvents its operation. A broader claim therefore can be advanced. ${ }^{84}$ To the extent that employment and labour protections do extend to migrant workers in agriculture, immigration law regulation serves to undercut these protections. The threat of repatriation proves central to this undercutting thereby clouding all work and wider social relations under the SAWP. Thus, immigration regulation subordinates labour regulation so that any formal gains made in terms of the latter will likely be stifled by the former. ${ }^{85}$

81 Luin Goldring, Carolina Berinstein \& Judith Bernhard, "Institutionalizing Precarious Migratory Status In Canada" (2009) 13:3 Citizenship Studies 239.

82 See Tucker, supra note 40 (surveying provincial collective bargaining legislation applicable to agricultural workers ranging from Ontario's creation of an alternative regime, the $A E P A$, to other provincial labour relations statutes). With respect to collective representation, the current exclusion of agricultural workers in Ontario from collective bargaining rights formally accessible by most other categories of worker under the $L R A$, notwithstanding the Fraser ruling, produces a vacuous and less than meaningful freedom of association. Their inclusion under the distinct and highly restrictive $A E P A$, which permits collective organization only in the form of worker associations but denies the right to bargain collectively and to take collective action through strike activity, undermines formal channels for collective action.

83 Employment Standards Act, 2000, SO 2000, c 41, s 74(1).

84 The same argument would hold under the $L R A$, if it were to apply to agricultural workers.

85 Within the context of Canada's system of complex federalism, federal policies and programs sometimes overlap and interfere with the authority of the Ontario government to act. The resolution of these jurisdictional conflicts over policy 
The SAWP functions through the ongoing and mutually reinforcing interaction of mobilizing and immobilizing regulatory controls imposed on migrant farm workers. Migrant farm workers are mobilized to cross national territorial borders only to be immobilized, in distinct and myriad ways, within Canada. ${ }^{86}$ Governed by these regulatory dynamics, the SAWP workers who make the annual trek to harvest crops in fields and greenhouses in Canada are subjected to state-sanctioned limits on labour market and geographic mobility and on migratory status. ${ }^{87}$ The mobilize-to-immobilize dynamic, which frames the relations and conditions of unfreedom in which migrant farm workers find themselves, captures the transnational regulatory contours of agricultural labour migration to Canada.

Yet, to the extent that methodological transnationalism portends to depoliticized, ahistorical analysis, a more pointed framework of analysis is needed. Unfree labour migration regimes highlight a deep contradiction within capitalism between claims to the existence of free wage labour and the stubborn persistence of unfreedom. Grounded on capital's fundamental dependence on labour, which appears even more pronounced in the case of growers within the SAWP, this contradiction appears explicit in the hyper-competitiveness of the neoliberal moment. For one, the ongoing need for unfree labour in agriculture means that Caribbean and Mexican workers and their respective sending states are pitted against each other in competition for the meagre benefits that accrue from temporary labour migration. ${ }^{88}$ These workers (and states) may face exclusion by virtue of their efforts to collectively resist, and workers from alternative locales will be incorporated to serve this need. Not only do existing SAWP workers and their respective states compete but, with the introduction of additional migrant agricultural recruitment streams, the competition in fact has widened. The amplified competition represents a distinctive dimension of labour migration in contemporary global capitalism. That said, while agricapital may appear freed from national constraints, and this is furthered by the hyper-competitive context in which contemporary migration unfolds, in fact its reliance upon labour renders it beholden to the politico-legal interventions of states, sending and receiving. ${ }^{89}$

matters is said to lie at the heart of addressing policy deficiencies. However, federalism tends to serve as an excuse or justification for policy failure and not a means for resolution.

This stands in contrast to the experiences of European immigrant workers at the turn of the twentieth century. How early European immigrant workers and their families experienced citizenship was contingent on the occupational experiences of the largely male breadwinners. In the early twentieth century, as Donald Avery notes, "[g]eographical mobility and occupational pluralism typified the European immigrant experience. ... In one year an immigrant worker might find himself cast in many roles: in February a lumber worker in Iroquois Falls, Ontario; in June a railroad navvy along the National Transcontinental; in August a harvester in Grenfell, Saskatchewan; in November a coal miner in Fernie, British Columbia" Donald Avery, Dangerous Foreigners: European Immigrant Workers and Labour Radicalism in Canada, 1896-1932 (Toronto: McClelland \& Stewart, 1983) at 8. These varied experiences point not just to "occupational diversity", challenging simplistic antinomies of agricultural and non-agricultural forms of paid work. Just as profoundly, the transience of these workers reveals the crucial importance of geographic or spatial mobilization within early migration experiences.

87 One fear is that as the mobilize-to-immobilize dynamic repeats each season, it becomes more deeply entrenched and the constraints imposed on labour market circulation and spatial mobility appear more hardened.

88 See Satzewich, "Business", supra note 65.

89 Even as mechanization and biotechnological inventions appear to be reducing its labour dependence, agri-capital itself remains deeply embedded within these conditions and relations of unfreedom. How migrant workers and their allies might press these contradictions to seek a break from the hierarchical state system and the uneven logic of global capitalism, is the real question going forward. 
It is precisely agri-capital's deep dependency on cheap, flexible and readily exploitable labour that explains the contemporary configuration of temporary labour migration in Canada. In other words, the reliance on migrant labour in Canadian agricultural production is not a historical accident. Its logic and systematicity turns on the racialized articulations of capitalist development, and in particular racialized class inequalities within and across national states, or what has been termed global apartheid. ${ }^{90}$

\section{Labour Law Unhinged}

Prevailing labour law scholarship and practice has shown a striking indifference to the racialized class dimensions of Fraser and of the wider context of agricultural labour production. Migratory status and the threat of repatriation function to immobilize migrant workers and as such disrupt the operation of existing (and prospective) employment and labour law protections. This leads to the conclusion that modest employment and labour reforms in and of themselves cannot produce meaningful gains for migrant workers. It also points to the fundamental importance of confronting differential incorporation and treatment as it originates in labour unfreedom and through specific mechanisms of immobilization. An explicitly transformative political agenda against unfree migrant labour must take seriously ongoing resistance struggles and, at once, the racialized class obstacles entrenched in law. The lack of recognition of the resistance efforts mounted by workers against the particularly acute racialized class antagonisms they encounter, is illustrative of the deep impacts of the processes of racialization and racism. What becomes evident is that racialization and racism are at play as concrete explanations, not only of the differential incorporation of peoples from the global South as unfree migrant labour, but also in understandings of the self-organizing potential of workers so categorized. Processes of racialization serve as constraints in worker struggles and prevailing conceptual frameworks.

The way forward, as I see it, is to inscribe a migrant justice movement grounded not merely on antiracist, anti-capitalist, anti-colonialist and anti-imperialist protest struggles, notwithstanding the pivotal nature of each of these. A requisite pursuit is the articulation of a transformative political vision and agenda aimed at confronting the hyper-exploitation of migrant labour through national states for the benefit of capital and capital accumulation. ${ }^{91}$ A more modest pursuit drives this final section. The preceding analysis reveals serious deficiencies in scholarly approaches to labour law. Labour law orthodoxy, through its strict association with the institutional paraphernalia of industrial unionism, cannot fully capture the legal regulation of agricultural labour production. In response, I contend that there is a deep-seated need to unmoor or unhinge understandings of legal regulation of labour from this orthodoxy. How scholars might undertake such a task forms the basis of the remainder of this article. I identify two areas in which legal scholars concerned with migrant worker justice might unhinge the study of labour law. These areas are derived from the central finding of the preceding analysis, that

90 Adrian A Smith, "Pacifying the "Armies of Offshore Labour"” (2013) 9:2 Socialist Studies 78 ["Smith, Pacifying"]; Sharma, supra note 75. For a more general application of the argument to Canadian labour markets see Grace-Edward Galabuzi, Canada's Economic Apartheid: The Social Exclusion of Racialized Groups in the New Century (Toronto: Canadian Scholars, 2006).

91 Status on arrival offers a useful strategic intervention that would remove repatriation as a constant threat to collective action. Tied together with family reunification, and with non-traditional forms of collective representation where workers retain their full authority to collectively withdraw their labour power, these initiatives could open space for migrant agricultural workers to pursue an emancipatory agenda for human development. 
racialized class dynamics shape the politico-legal obstacles or impediments encountered by migrant agricultural workers under Canada's SAWP.

First, scholarly accounts must become attentive to the self-organizing efforts of migrant agricultural workers. The mobilize to immobilize dynamic erodes the self-organizing potential of workers and, coupled with the spatial dispersal of farms across the countryside, works to disjoint and thus undermine actually existing resistance. Strategies for moving forward must tackle these impediments in a sober and concerted manner. Crucially, the challenge rests with consolidating, broadening and fortifying the disjointed forms of migrant worker resistance currently undertaken. Reformulating the problematic in this way forces us to take seriously specific obstacles to consolidation and sustained direct action. It is in this way that scholarly accounts must be alive to the self-organizing potential of SAWP workers. Claims based on the need for direct action that do not account for actually existing resistance lead to a skewed assessment of workers' self-organizing potential.

In contrast to a focus on elites, the work of unhinging requires a deeper reliance upon "bottom-up" accounts of collective organizing and action. ${ }^{92}$ David Featherstone's Solidarity: Hidden Histories and Geographies of Internationalism, which articulates a history of internationalism from below constructed through dynamic and inventive political struggle, provides a compelling recent example. ${ }^{93}$ Featherstone identifies the forging of "solidarities from below" as "central mobilizing practices" and a "powerful force" which construct "forms of agency and political activity" designed "to challenge forms of oppression" and "to make the world anew". ${ }^{94}$ In providing a basis in which to "locate solidarity as a transformative relation ... [based on] the active creation of new ways of relating", ${ }^{95}$ Featherstone's account supports an alternative approach to the study of the legal regulation of agricultural labour, one divorced from the belief that industrial unionism provides a workable way forward. ${ }^{96}$

The utility of an unhinged approach of this kind was illuminated in Fraser by how the UFCW refrained from arguing in support of the right to strike as a mechanism of dispute resolution for agricultural workers. ${ }^{97}$ The unwillingness of the UFCW to claim strike action as necessary in the

92 This reflects the growing move to problematize industrial unionism as historically contingent institutions within neoliberal capitalism while remaining partial to the indispensability of myriad forms of collective action in social relations. See e.g. Thom Workman, If You're In My Way, I'm Walking: The Assault On Working People Since 1970 (Black Point, NS: Fernwood, 2009); David Camfield, Canadian Labour In Crisis: Reinventing the Workers' Movement (Halifax, NS: Fernwood, 2011).

93 David Featherstone, Solidarity: Hidden Histories and Geographies of Internationalism (London: Zed Books, 2012).

$94 \quad$ Ibid at $4 ; 5$.

95 Ibid at 5. Featherstone refers also to 'internationalism' -- as distinct from transnationalism which tends to lack an explicit political project and agenda -- but rejects "top-down accounts which focus on hierarchical forms of left political organization" Ibid at 8. In its place, he envisions an internationalism grounded on "the generative world-making possibilities of subaltern political activity" Ibid at 9. In this, he emphasizes "the role of subaltern geographies of connection in constructing internationalisms" Ibid at 9 -- an "internationalism from below", as he frames it. Ibid at 12. This marks an attempt at transcendence of methodological nationalism which grips our ways of knowing and acting, including within law, but not for the sake of inserting a depoliticized transnationalism. Rather the intention is to open up transformative political possibilities.

96 There is a need for a new conception of the migrant labour and legal regulatory relationship, one that transcends prevailing disciplinary orthodoxies, including within the fields of labour law and immigration law.

97 See Fudge, supra note 25 at 10. This lack of insistence on the necessity of strike action, perhaps the product of the everpersistent self-disciplining exercise in which lawyers typically engage -- marked by a moral economy which 
exercise or defence of freedom of association allowed the juxtaposition of the rights of labour against the rights of capital evident in the $A E P A^{98}$ to continue without questioning. The "business case" pointing to the uniqueness of agricultural production stemming from the harvest imperative, as articulated in the AEPA, must not go unchallenged. A bottom-up internationalist perspective concerned with consolidating actually existing resistance would conceive of the UFCW's actions as an affront. It would advocate the adoption of a politics that rejects the need for state approval of the collective withdrawal of labour power. An unhinged approach, as such, supports efforts to renew agricultural worker organizing outside of the governing labour relations statute. ${ }^{99}$

An unhinged approach formulated on bottom-up internationalism would also extend the analysis beyond the confines of the Canadian national state. A nation state-centred account poses limits to our understanding of how migrant labour is regulated and how internationalist political activities might foster challenges to racialized class oppression. A focus on the solidarity activities of J4MW, for instance, would unearth mobilizing practices aimed at overcoming the aforementioned politico-legal obstructions. The approach also encourages excavation of the political activities of migrant workers, including when they return back to their "home" states. In both ways, an unhinged labour law could contribute both to mapping the intricate web of transnational politico-legal constraints and to fortifying the infrastructure of collective action and struggle against oppression.

Second, labour law unhinged is a call for analytical reorientation. It should be oriented not around the (decaying) institutions of industrial unionism but alternative nodes of activity. ${ }^{100}$ A crucial node of activity is the productive rendering -- or pacification -- of labour for capital accumulation. ${ }^{101}$ SAWP workers are pacified in Canada in racialized, unfree and migrant forms which occur primarily through the regulatory interventions of interconnected national states. ${ }^{102}$ Reorientation around the transnational regulatory dynamics of human $\mathrm{im} /$ mobility facilitates interrogation of the role of national states in facilitating capitalist relations of production. Further, the pacification of migrant labour both relies on

reduces/truncates/stifles/de-radicalizes the most incisive dimensions of political claims under the belief that they 'just won't work in court' -- smacks of paternalism in its suggestion that they know best for workers.

98 Recall that the $A E P A$ considers the "unique characteristics of agriculture, including, but not limited to, its seasonal nature, its sensitivity to time and climate, the perishability of agricultural products and the need to protect animal and plant life" (supra note 25 at s. 1(1)).

99 This is an analysis many scholars and organizers have discussed for some time. See e.g. Tucker, supra note 40 . For a more general application of this perspective to non-agricultural workers see Bryan Palmer, "What's Law Got To Do With It - Historical Considerations on Class Struggle, Boundaries of Constraint, and Capitalist Authority" (2003) 41:2/3 Osgoode Hall LJ 465. But because, as this preceding analysis suggests, statutes and legal regimes governing migrant agricultural labour extend beyond 'labour law' proper to incorporate immigration regulation, the notion of organizing outside the statute needs certain revision.

I would add that the aim of unhinging labour law is to facilitate a certain degree of analytical 'free floatedness' in which a variety of theoretical constructs, methodologies and epistemologies are employed to re-imagine the study of the interaction between labour and law.

101 See e.g. Mark Neocleous \& George Rigakos, eds, Anti-Security (Ottawa: Red Quill Books, 2011).

102 For an elaboration on the concept of pacification in the context of migrant labour regulation in Canada see Smith, "Pacifying", supra note 90. 
and perpetuates global apartheid. ${ }^{103}$ A reorientation toward understanding the ways in which states work to pacify labour requires a keen attentiveness to impacts of and on global apartheid conditions. ${ }^{104}$

Ultimately, the work of unhinging labour law demands a commitment to a transgressive agenda and generative practices aimed at venturing away from the centre of labour law orthodoxy, industrial unionism, toward the margins and marginalized workers. It is these sorts of practices which would lend dire support to ongoing attempts to secure justice for migrant workers.

\section{CONCLUSION}

In this article I undertook an anti-racist class analysis of the legal regulation of migrant agricultural labour production. Commencing with a critique of the absence of concerted class analysis within critical race theory, I turned to an examination of recent scholarly accounts of the Supreme Court of Canada's Fraser ruling on the associational freedom of agricultural workers in Ontario and then, in linking these to scholarship calling for a "direct action" approach to migrant justice, I engaged with the legal and extra-legal struggles of migrant agricultural workers. Prevailing scholarly accounts of agricultural production in Canada tacitly have taken the legal strategies of trade unions as proof of what agricultural workers and their allies want. Even where the legal-pacifist strategies of trade unions are problematized, the resistance struggles of workers are regarded as an exception and not the rule. In both respects, the racialized class construction of migrant farm workers remains under-examined and unchallenged. This was brought home to me in the Supreme Court's allocation of space during the Fraser hearing in which lawyers and the justices claimed space in the courtroom while migrant workers in attendance were forced to observe the proceedings from the overflow room. Yet, all of the ways forward as currently constructed appear fraught: legal action as evidenced in Fraser has sidestepped the racist dimensions of agricultural labour exploitation, extra-legal action has been framed in ways un-attentive to racism; each, in their own ways, reinforce racialization and racism.

The "structural necessity" of migrant labour to agricultural production in Canada requires analytical attention. ${ }^{105}$ Building on the prevailing political economy framework, the characterization of seasonal agricultural workers as unfree migrant labour turns on the formative role of the Canadian state in imposing politico-legal constraints. These constraints, which develop through interactive forms of

103 Ibid.

104 Importantly, further work is needed to sharpen the interconnections between anti-racist class analysis and the emergent apartheid conditions of global capitalism. This is particularly important for migrant justice struggles. Because labour unfreedom develops within and through racist practices of the state, designed to mobilize and immobilize workers within the labour market, including in terms of benefits and protections, and spatially, collective resistance must take forms that confront racism and capitalist imperialism. Although quite effectively harnessed to serve capitalist ends, racism is not a mere capitalist invention that will wither away with the cessation of labour exploitation. In viewing unfree migrant labour as a racist idea and practice that gains its potency in the intersecting authority of immigration and labour regulation, we are forced to ground all political engagements within an explicitly anti-racist, anti-capitalist framework. The task then is to situate racialization and racism as pivotal processes in the hyper-exploitation of migrant agricultural labour without reducing labour unfreedom to these processes alone.

105 Basok, supra note 65. See also Mark Thomas, "Labour Migration and Temporary Work: Canada's Foreign-Worker Programs in the "New Economy"' in Norene Pupo \& Thomas, eds, Interrogating the New Economy: Restructuring Work in the 21 st Century (Toronto: University of Toronto Press, 2010) 149. For sustained analysis see Smith, "Pacifying", supra note 90. 
regulation seeking to mobilize and immobilize workers within the labour market, including in terms of the diminished associational freedom endorsed in Fraser, and within the territorial border of Canada, obtain through the racist practices of the Canadian receiving state and are bolstered by the supportive practices and policies of labour-sending states. The SAWP workers who make the annual trek to harvest crops in fields and greenhouses in Canada are governed by these transnational regulatory dynamics of mobilization and immobilization which frame the specific relations and conditions of unfreedom in which they find themselves. In particular, the insertion of workers into precarious migratory status backed by the threat of repatriation, which is wielded by growers through the authority of the Canadian state, functions to thwart concerted collective worker resistance. That threat has proven stubbornly persistent in disrupting worker organizing efforts on the ground, although breakthroughs have been made, including work stoppages on specific farms and the historic Pilgrimage to Freedom trek. ${ }^{106}$

If the task is to find ways for the self-organizing and creative capacities of workers to flourish, the politico-legal mechanism of unfree labour proves obstructionist to this aim. It seems quite understandable that, consistent with well-entrenched political misgivings, a turn to the courts should be done with deep skepticism. ${ }^{107}$ That skepticism seems even more pressing in view of the centrality of the racist state practices in which courts operate. My fateful trip to the Supreme Court of Canada in December 2009 illustrated all too well this context of racialized class injustice. Yet, organized labour's leadership, and the working class more generally, perpetuate racism as well. And in this regard, migrant workers and marginalized activists like those at the core of J4MW should not have to carry all of the burden for the legal-pacifistic failings of organized labour.

The failure to properly account for these forms of resistance raises important questions around our analytic, but also presents concrete problems for the advocates of direct action. The aim is not to overcome the supposed collective docility and acquiescence of agricultural workers -- a denial of human agency that, in its worst forms, reinforces racism -- to somehow activate the revolution within each of them. The challenge, instead, is to assist in consolidating, broadening and fortifying the forms of worker struggles currently undertaken. Because we cannot have a radical human emancipatory movement without radical human emancipatory theory, that challenge is one of praxis which is necessarily openended and by definition cannot be pre-determined, but which must be taken up in the interplay between reflection, theory and action. Legal scholars and lawyers can forcefully contribute to the development of a transformative praxis and agenda of migrant worker justice -- but they must do so by turning away from prevailing approaches to the study and practice of labour law and toward a transgressive and openly oppositional agenda concerned with confronting the racialized injustice of capitalist agricultural production.

\footnotetext{
106 See Goutor \& Ramsaroop, supra note 61. For a discussion, see supra note 61.

107 Fudge \& Glasbeek, supra note 3.
} 